\title{
Revisiting Authentic Assessments: When COVID-19 Restricts Traditional Intelligence Testing
}

\author{
Angela F Watkins* \\ Department of Psychology, Spelman College, Spelman Lane, Southwest, Atlanta, Georgia, USA
}

Submission: December 07, 2020; Published: December 15, 2020

*Corresponding author: Angela F Watkins, Department of Psychology, Spelman College, Spelman Lane, Southwest, Atlanta, Georgia, USA

Abstract

Intelligence testing is consistently and widely used by psychologists the world over. Intelligence testing is used as a primary tool for the identification of learning disabilities and typically administered in a closed setting. However, shortcomings of traditional intelligence tests are documented, and restrictions associated with the COVID-19 virus now make it difficult for the test taker and the test administrator to be in close proximity to each other. Authentic assessments, a measure of real and adaptive skills, warrant revisiting. This paper points to the shortcomings of traditional intelligence testing and lifts authentic assessment as a viable option.

Keyword: Intelligence testing; Authentic assessment; Psychologists; Learning disabilities

Revisiting Authentic Assessments When COVID-19 Restricts Traditional Intelligence Testing Highly regarded for diagnosing ability and for decision making about instructional delivery, intelligence testing is a well-established practice. Intelligence tests are among the most consistently and widely used measures by psychologists the world over, and as a primary tool for the identification of learning disabilities [1-4].

Despite the widespread use of intelligence testing, the shortcomings of these instruments are well documented [511]. More often than not, intelligence tests result in minimized resources and closed doors, for those whose scores are among the lowest [12-14], the availability of which would otherwise make a significant difference for learners with learning disabilities. As an example, students belonging to minority groups are often overrepresented in special education programs and underrepresented in gifted and talented programs [15]. One might easily wonder whether intelligence testing is intended to be helpful or hurtful.

To this end, Dr. Asa G Hilliard [16] put forward the question, "What good is this thing called intelligence and why bother to measure it?" The question bears repeating, what is intelligence and why bother measuring it? While this question hangs over, there is also now a clarion call for all lives matter and it most certainly reaches the practice of teaching and learning. It serves as a reminder that every child should be afforded with equitable assessment, in order that each learner might reach the heights and depths of intellectual prowess. This should be the case whether and to what extent a disablement exists. The time is appropriate, perhaps more than ever before, to consider how that the shortcomings of traditional intelligence tests are impacting the current and future lived experiences of learners with disabilities.

Moreover, in this season of COVID-19 virus spread, traditional intelligence testing is found lacking. Before COVID-19, intelligence tests were typically administered individually. That is, a psychologist administers the test to an individual in a closed setting [17]. Then, the psychologist scores and interpret the results using both qualitative and quantitative interpretations. Qualitative interpretation requires the psychologist to consider the testing process, if and how a test taker completes the test. Quantitative interpretation requires the psychologist to consider the numerical score. Finally, the psychologist has to also consider within person performance and performance compared to a norm group [18]. The long and short of it is that this process reveals more about what a learner can't do than what he or she can do. 
Given that the shortcomings of traditional intelligence testing are well documented and that the current restrictions brought about as a result of the spread of the COVID-19 virus makes it difficult for the test taker and the test administrator to be in close proximity to each other, authentic assessments are a viable option.

Authentic assessments, unlike traditional intelligence tests, measure real and adaptive skills, revealing what a learner can do, more than what they can't do. Neisworth \& Bagnato [19] suggested doing away with decontextualized testing practices, as is the case of traditional intelligence testing, and using measurements that yield authentic explanations of skills that exceptional children naturally utilize as they navigate everyday situations.

Knowing more about what learners can actually do is what gets them to suitable accommodations and the realization that they have real value and skills. Authentic assessments lead to life outcomes that are meaningful, especially for children with severe disabilities [20] Authentic assessments lead to the adaptation of various academic skills, including language [21].

Returning to the question of why bother measuring intelligence, if the goal is for learners with disabilities to be in inclusive and least restrictive learning environments and with high quality instructional resources, the increased use of authentic assessments will bring it about. The effort to measure intelligence becomes worthwhile when it is indeed authentic.

\section{References}

1. Benson E (2003) Intelligent intelligence testing. Monitor on Psychology 34(2): 48-58.

2. Kamphaus RW (2019) Clinical assessment of child and adolescent intelligence. Springer.

3. Rabin L, Barr W, Burton L (2005) Assessment practices of North American Clinical Psychologists: a survey of INS, NAN, and APA Division 40 members. Archives of Clinical Neuropsychology 20(1): 33-65.

4. Saklofske DH, Weiss LG, Breaux K, Beal AL (2016) WISC-V and the evolving role of intelligence testing in the assessment of learning disabilities. In: LG Weiss, DH Saklofske, JA Holdnack, A Prifitera (Eds.), WISC-V assessment and interpretation: Scientist-practitioner perspectives: pp. 237-268.

5. Alfano M, Holden L, Conway A (2016) Intelligence, race, and psychological testing. The Oxford Handbook of Philosophy and Race: pp. 474.

6. Guthke J (1993) Current trends in theories and assessment of intelligence. In JHM Hamers, AJJM Ruijssenaars, K Sijtsma (Eds.) Learning potential assessment: P. 13-20.

7. Guo W, Chen Y, Liu S, Zhang X (2019) Intelligence Testing.

8. Hilliard A G (1984) IQ Testing as the Emperor's New Clothes. In: Reynolds CR, Brown RT (Eds.) Perspectives on Bias in Mental Testing. Perspectives on Individual Differences. Springer, Boston, MA.

9. Hilliard A G III (1990) Misunderstanding and testing intelligence. In: JI Goodlad, P Keating (Eds.), Access to knowledge: An agenda for our nation's schools: pp. 145-157. College Entrance Examination Board.

10. Snyderman M, Rothman S (1987) Survey of expert opinion on intelligence and aptitude testing. American Psychologist 42(2): 137144 .

11. Valencia RR, Suzuki LA (2001) Intelligence testing and minority students: Foundations, performance factors, and assessment issues (3). Sage Publications.

12. Butler HA, Pentoney C, Bong MP (2017) Predicting real-world outcomes: Critical thinking ability is a better predictor of life decisions than intelligence. Thinking Skills and Creativity 25: 38-46.

13. Harrison LM, Hasan S (2019) Promoting Educational Equity through Democratizing Intelligence. In: The Handbook of Dewey's Educational Theory and Practice: pp. 205- 220. Brill Sense.

14. Wasserman JD (2018) A history of intelligence assessment: The unfinished tapestry. In: DP Flanagan, EM McDonough (Eds.), Contemporary intellectual assessment: Theories, tests, and issues: $p$. 3-55. The Guilford Press.

15. Yekovich FR (1994) Current issues in research on intelligence. Practical Assessment, Research, and Evaluation 4(1).

16. Hilliard, A. G. (1994). What good is this thing called intelligence and why bother to measure it? Journal of Black Psychology 20(4): 430-444.

17. Reynolds CR (1998) Comprehensive clinical psychology: Vol 4: Assessment. Pergamon/Elsevier Science Ltd.

18. Freeman AJ, Chen YL (2019) Interpreting pediatric intelligence tests: A framework from evidence-based medicine. In G. Goldstein, D. N. Allen, \& J. DeLuca (Eds.), Handbook of psychological assessment. p. 65-101. Elsevier Academic Press.

19. Neisworth JT, Bagnato SJ (2004) The mismeasure of young children: The authentic assessment alternative. Infants \& Young Children 17(3): 198-212.

20. Horn E, Parks S, An Z (2019) Inclusive Special Education for young learners with severe and multiple disabilities. Advances in Special Education 34: 119-137.

21. de Sam Lazaro S L (2017) The importance of authentic assessments in eligibility determination for infants and toddlers. Journal of early intervention 39(2): 88-105. 
(C) (i) This work is licensed under Creative Commons Attribution 4.0 License BY DOI: 10.19080/GJIDD.2020.07.555709

\section{Your next submission with Juniper Publishers} will reach you the below assets

- Quality Editorial service

- Swift Peer Review

- Reprints availability

- E-prints Service

- Manuscript Podcast for convenient understanding

- Global attainment for your research

- Manuscript accessibility in different formats ( Pdf, E-pub, Full Text, Audio)

- Unceasing customer service

Track the below URL for one-step submission https://juniperpublishers.com/online-submission.php 